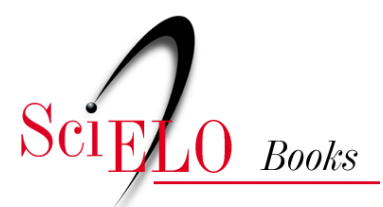

\title{
18. A Primeira Operação Cesariana em Parturiente Viva
}

\author{
Joffre Marcondes de Rezende
}

\section{SciELO Books / SciELO Livros / SciELO Libros}

REZENDE, J. M. A Primeira Operação Cesariana em Parturiente Viva. In: $\grave{A}$ sombra do plátano: crônicas de história da medicina [online]. São Paulo: Editora Unifesp, 2009, pp. 171-172. História da Medicina series, vol. 2. ISBN 978-85-61673-63-5. https://doi.org/10.7476/9788561673635.0019.

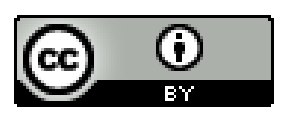

All the contents of this work, except where otherwise noted, is licensed under a Creative Commons Attribution 4.0 International license.

Todo o conteúdo deste trabalho, exceto quando houver ressalva, é publicado sob a licença Creative Commons Atribição 4.0.

Todo el contenido de esta obra, excepto donde se indique lo contrario, está bajo licencia de la licencia Creative Commons Reconocimento 4.0. 


\section{A Primeira Operação Cesariana em Parturiente Viva}

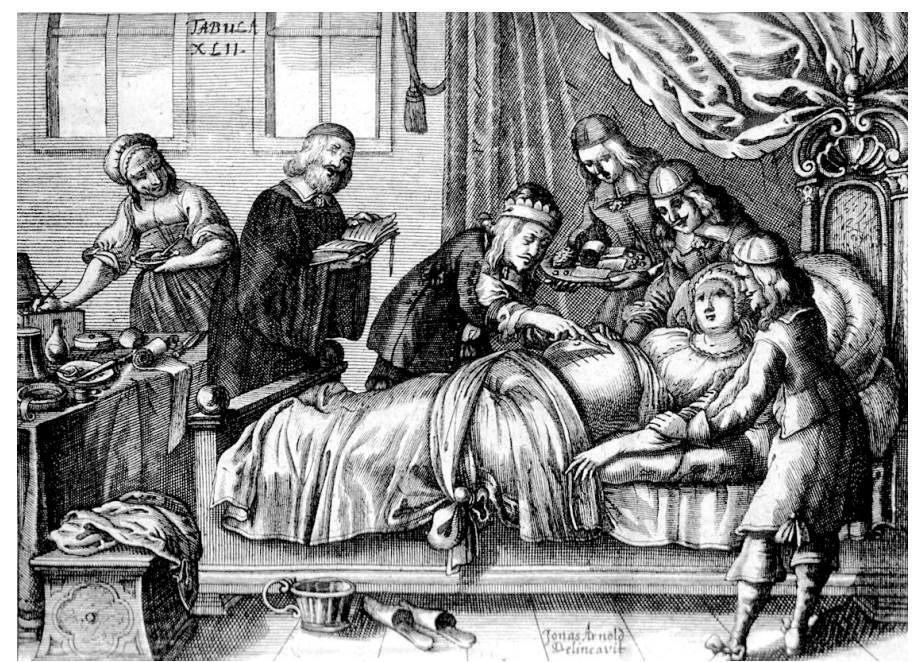

Gravura em madeira de Jonas Arnold, séc. XVI, que mostra uma operação cesariana.

A operação cesariana na Antiguidade só era praticada após a morte da parturiente, com a finalidade de salvar o feto ainda com vida. Desde 700 a.C. a lei romana proibia os funerais de toda gestante morta, antes que se fizesse a cesárea para retirada do feto. Os fetos que nasciam com vida eram chamados cesões ou césares (Vieira, I 87 I-I 874).

A cesárea em vida, como alternativa de parturição, é bem mais recente.

É interessante conhecer a história da primeira cesárea em vida de que se tem notícia (Graham, I957). Foi realizada em I 500, em Sigershaufen, pequena cidade da Suíça, por Jacob Nufer, em sua própria esposa. Jacob Nufer não era médico e nem sequer cirurgião-barbeiro. Era um homem simples do povo, habituado a castrar porcas.

Sua mulher, primípara, entrou em trabalho de parto e, como era de hábito na época, estava sendo atendida por parteira. Por alguma razão, a criança não nascia. Desesperado, o marido chamou uma a uma, todas as parteiras do lugar, num total de treze. Depois de muitas tentativas e de longa espera, vendo que as forças de sua esposa se exauriam, apelou para os cirurgiões-barbeiros do 
lugar, acostumados a praticar a talha hipogástrica para retirada de cálculo vesical, a fim de que fizessem a operação cesariana em sua esposa.

A simples ideia de um cirurgião-barbeiro atender a uma parturiente já constituía um fato inédito que contrariava todos os costumes da época. Nenhum deles atreveu-se a prestar socorro à infeliz mulher.

Nufer decidiu, então, solicitar permissão às autoridades civis da cidade para praticar, ele mesmo, a operação cesariana em sua esposa. Auxiliado por duas parteiras mais corajosas, colocou sua mulher sobre uma mesa e com uma navalha abriu-lhe o ventre. Diz a crônica que o fez com tal habilidade que a criança foi removida de um só vez, sem provocar qualquer dano à mãe ou no filho. As outras onze parteiras que aguardavam do lado de fora, ao ouvirem o choro da criança, quiseram entrar, no que foram impedidas, até que Nufer procedesse ao fechamento da incisão, tal como fazia com as porcas que ele castrava. Houve cicatrização da ferida e a parturiente recuperou-se integralmente, tendo tido no decorrer de sua vida outras cinco gestações, com partos normais, um dos quais gemelar. A criança, que resistira à ação de treze parteiras e à intervenção cirúrgica, teve desenvolvimento normal e viveu 77 anos.

A introdução da cesárea na prática obstétrica só teve início a partir do século XVIII. Tinha uma alta mortalidade fetal e materna e só era praticada em casos muito especiais. Langaard ( I 873), em seu Dicionário de Medicina Doméstica e Popular, dá-nos o seu testemunho: "Apesar de que não se pode admitir que a operação seja absolutamente mortal, é o numero das operadas que escapam muito limitado". A preferência dos obstetras era para o uso do fórceps ou, se necessário, a embriotomia. Somente no século xx a cesárea tornou-se uma operação rotineira.

No Brasil, a primeira operação cesariana é creditada ao dr. José Correia Picanço, barão de Goiana, tendo sido realizada em Pernambuco no ano de I 822.

\section{Referências Bibliográficas}

Graham, H. Surgeons all. New York, Philosophical Library, I957.

Langand, T. J. H. Dicionário de Medicina Doméstica e Popular, $2^{\underline{a}}$ ed. Rio de Janeiro, Laemmert, I 873 .

Vieira, D. Grande Dicionário Portuguez ou Tesouro da Lingua Portugueza. Porto, Ernesto Chardron e Bartholomeu H. de Moraes, I 87I-I874. 